\title{
Hong Kong and the Indo-Chinese Refugees: Reflections on the International Refugee Environment
}

Alex Cunliffe

\begin{abstract}
The plight of the Vietnamese Boat People in Hong Kong in recent decades has brought into sharp relief the changing character of the international refugee political environment. Over the last twenty years asylum seekers from Vietnam arriving in the former colony have experienced a dramatic change in their reception, treatment and fortunes. For many academic observers, this has highlighted the problems facing the major actors, including the United Nations High Commissioner for Refugees (UNHCR), within the international refugee regime. This short article highlights this metamorphosis and illustrates that the refugee issue remains unresolved in Hong Kong despite the recent handover to Beijing.
\end{abstract}

\section{Précis}

La situation difficile des Boat Peoples vietnamiens à Hong Kong dans les dernières décennies a jeté une lumière crue sur la caractère changeant de l'environnement politique des réfugiés internationaux. Au cours des vingt dernières années les demandeurs d'asile politique originaires du Vietnam débarquant dans l'ancienne colonie britannique ont vu la réception leur étant faite se modifier dramatiquement. Il en est autant de la façon dont on les traite et des opportunités qui leur sont allouées. Pour les observateurs du champ académique, ces faits ont mis en relief les problèmes auxquels font face les principaux intervenants, y compris le Haut Commissariat des Nations Unies pour les réfugiés, dans le cadre du régime international pour les réfugiés. Ce court article décrit cette métamorphose et illustre le fait que la question des réfugiés demeure irréso-

Alex Cunliffe, Ph.D., is Principal Lecturer in the Department of Politics at the University of Plymouth, Plymouth, United Kingdom. lue en dépit de la récente rétrocession de Hong Kong d la Chine.

\section{Introduction}

On July 1, 1997, the British formally handed Hong Kong over to the Chinese Government. In the months leading up to the handover, a substantial amount of academic analysis and media attention focused upon the implications of decolonization for the indigenous Chinese community in Hong Kong. ${ }^{1}$ However, by March of the same year, barely three months before Beijing took control, there were still 5,000 Indo-Chinese asylum seekers registered in UNHCR camps in Hong Kong. The plight of these people, sometimes referred to as "Vietnamese Boat People," should also have been cause for international concern. The Beijing Government made no secret of its desire not to inherit a refugee presence in Hong Kong. In 1995, Mr. Cheng Shousan, the Beijing Minister of Foreign Affairs Division Chief for Hong Kong and Macau, announced that immediately after the handover of sovereignty, Hong Kong would cease to offer port of first asylum status. As of July 1997, the UNHCR reported that there were still 1,318 Vietnamese refugees in Hong Kong, of whom only 260 are under consideration for resettlement in third countries. In addition, there are 195 Vietnamese nationals who have been denied refugee status and $a$ further 512 people who are recognized neither as refugees nor as $\mathrm{Vi}$ etnamese nationals by the Vietnamese Government. ${ }^{2}$ Thus, although it is over twenty years since the end of the Vietnam War, the international refugee community has still not resolved the issues created by the Vietnamese Boat People (VBP) and their search for political asylum.

As many observers are aware, the international treatment of refugees has undergone a dramatic metamorphosis over the last four decades. ${ }^{3}$ In large part, this appears to be a reaction to the changing nationality of the refugee population whose contemporary origins spring primarily from the less developed world. Of the three durable solutions to refugee movements presented by the United Nations High Commissioner for Refugees-namely integration, voluntary repatriation and resettlement-it would appear that repatriation (including mandatory repatriation) is the internationally preferred option. A brief examination of the fortunes of the Boat People arriving in Hong Kong since 1979 provides an interesting illustration of this changing political environment.

\section{Hong Kong and the Vietnamese Boat People}

In 1979, at the United Nations Conference on Vietnamese Boat People in Geneva, the British Government announced that Hong Kong would act as a port of first asylum for all asylum seekers from Vietnam. The "Boat People" were to be treated in a relatively liberal fashion and those arriving in the colony during the late 1970 s and early 1980 s were granted the status of "mandate refugees." This involved accommodation in Open Camps such as the Kai Tak Transit Centre in Kowloon and Pillar Point in the New Territories and the opportunity to take up employment in the colony. More importantly during these years, the UNHCR and the wider international refugee community were largely successful in obtaining international resettlement destinations for the Boat People based in Hong Kong. In the years up to 1982 , over 95,000 VBP were resettled in countries such as the United States $(45,733)$ Canada $(14,507)$ and the United Kingdom $(11,989)$. This represented a resettlement rate of almost 92 
percent of those arriving in Hong Kong during these early years of flight from Vietnam.

\section{"Humane Deterrence"}

However, as the 1980s progressed, London and Hong Kong were becoming increasingly reactionary in their attitude towards asylum seekers from the less developed world. At a time when Chinese migrants from the mainland were being forcibly expelled, the indigenous community in Hong Kong began to perceive an injustice in the refugee status being accorded to the Vietnamese arrivals. Moreover, the West in general was exhibiting a less welcoming attitude towards refugee movements from the Third World who were not perceived to be of strategic or political value. On 2 July 1982, the Hong Kong Government abandoned the automatic process of housing new arrivals of VBP in open centres and introduced a more restrictive closed camp policy. From that date, Indo-Chinese asylum seekers arriving in Hong Kong were detained in closed camps like Whitehead which were administered by the Correctional Services Department. This more restrictive move was seen part of a policy of "humane deterrence."

In the short term, there was a decline in the number of arrivals from Vietnam. The "sailing season" of 1981 had witnessed 11,886 arrivals whilst the equivalent figure for 1985 was 1,167. However, this did not result in a long term resolution to the size of the refugee population in the colony. From 1982, the UNHCR found it increasingly difficult to maintain a robust resettlement program. For example, the number of refugees departing the colony for permanent destinations such as the United States, Canada and the United Kingdom dropped from 37,468 in 1980 to 4,754 in 1989. As a result, by the end of the decade when the arrivals of VBP began to increase yet again, the refugee population in Hong Kong had not declined substantially. By 1989 there were in excess of 56,000 Indo-Chinese asylum seekers based in the colony.

\section{Repatriation and Screening}

The failure of the closed camps policy to deter the flow of VBP resulted in an even more reactionary program in the colony. It was a program which began to place much more emphasis upon the need for repatriation of asylum seekers rather than resettlement. In 1988, a Status Determination Procedure was introduced whereby all VBP arriving in the colony after 16 June would be treated as illegal immigrants pending a screening procedure designed to challenge their claim for refugee status.

Justification for the introduction of this relatively restrictive policy focused upon the "changing characteristics". of the new Indo-Chinese arrivals:

Almost all the arrivals in the 1980s have been ethnic Vietnamese. In 1979 only $27 \%$ of arrivals were Vietnamese and the rest were Chinese. Since 1980 the balance between north and south Vietnamese has also changed with the proportion of northerners steadily increasing. In 1984, 28\% came from the northern part of Vietnam, in 1985 the proportion was $37 \%$, $53 \%$ in 1986 and the figure was $70 \%$ in 1987. The proportion of northerners has increased to $72.2 \%$ during 1988 and the available evidence suggests that most have left Vietnam for economic reasons. ${ }^{4}$

In this respect, the British Government deemed that VBP arriving in Hong Kong after 16 June 1988, tended not to be motivated by political or racial persecution and therefore were unlikely to qualify as genuine refugees under the terms of the 1951 Geneva Convention and the 1967 Protocol on the status of refugees. From the outset, this screening procedure was very successful in denying refugee status. Within the first two years, over 17,000 Boat People in Hong Kong were "screened out." Furthermore, following an International Conference on Indo-Chinese Refugees in June 1989, the UNHCR agreed to organize a "Voluntary Repatriation Program" as part of the Comprehensive Plan of Action. The "voluntary" nature of the program was boosted by offering financial al- lowances to the returnee (initially $\$ 50$ ) and over 26,000 , including over 18,000 who did not undergo the screening process, had been repatriated under this program by January 1993. In order to deal with those VBP who do not wish to return voluntarily, and for those "double-backers" who had gone to Vietnam under the voluntary scheme and then returned to the colony, the United Kingdom, the Hong Kong and Vietnamese Governments, the UNHCR and the International Organisation for Migration signed a Statement of Understanding on 29 October 1991. This agreement provided the basis for the Orderly Departure Program which is now the program under which Hong Kong's remaining "illegal immigrants" are being repatriated.

\section{Summary}

The manner in which Britain and Hong Kong transformed their policies towards the Vietnamese Boat People in the colony reflects in many ways the changing character of the international refugee environment. In the years up until 1982, the British Government laid claim to a liberal humanitarian tradition by offering Hong Kong as a place of first asylum. However, as the 1980s progressed, reaction to increasing numbers of asylum seekers from the less developed world became more hostile. The introduction of the Closed Centre policy of 1982 and the Status Determination Procedure in June 1988 reflected a growing opposition to refugee movements, whilst the signing of the Comprehensive Plan of Action implemented a preference for the repatriation of refugees. Similarly, in general terms, the Western world has become less willing to accept a largescale resettlement program and the reaction to aburgeoning refugee population appears to promote repatriation as the durable solution. In a post-Cold War environment when claims for refugee status spring mainly from third world crises, western policies towards asylum seekers appear to be more illiberal, and the capacity of the UNHCR to continue to promote dura- 
ble solutions other than repatriation becomes more circumspect.

It is interesting to note that, in Hong Kong the UNHCR has allowed itself to become a signatory to many of the policy changes. The UNHCR was unable either to prevent the introduction of the closed camp policy and the screening process or to introduce a more comprehensive resettlement program for the Boat People. More importantly, its role in the development of Comprehensive Plan of Action and the Orderly Return Program reflects the contemporary overwhelming preference of the international community for repatriation as a durable solution to refugee movements.

\section{Notes}

1. See, for example, J. Y.S. Cheng and P.C. K. Kwong, eds., The Other Hong Kong Report, Annual Publications (Hong Kong: Hong Kong Chinese University Press).

2. Statistical information provided by the Office of the United Nations High Commissioner for Refugees, "Statistics of Indo-Chinese Refugees/Asylum Seekers, Hong Kong Caseload," UNHCR, Geneva.

3. For an examination of the changing character of international refugee political environments, see for example, G. Loescher, ed., The Question of Refugees in International Relations (Oxford: Oxford University Press, 1988); B. Harrell-Bond, "Repatriation: Under What Conditions is it the Most Desirable Solution for Refugees? An Agenda for Research," African Studies Review, no. 32 (1989): 41-68.

4. Vietnamese Boat People in Hong Kong (Fact Sheet), Hong Kong Government, Refugees Division, Security Branch, August 1989.

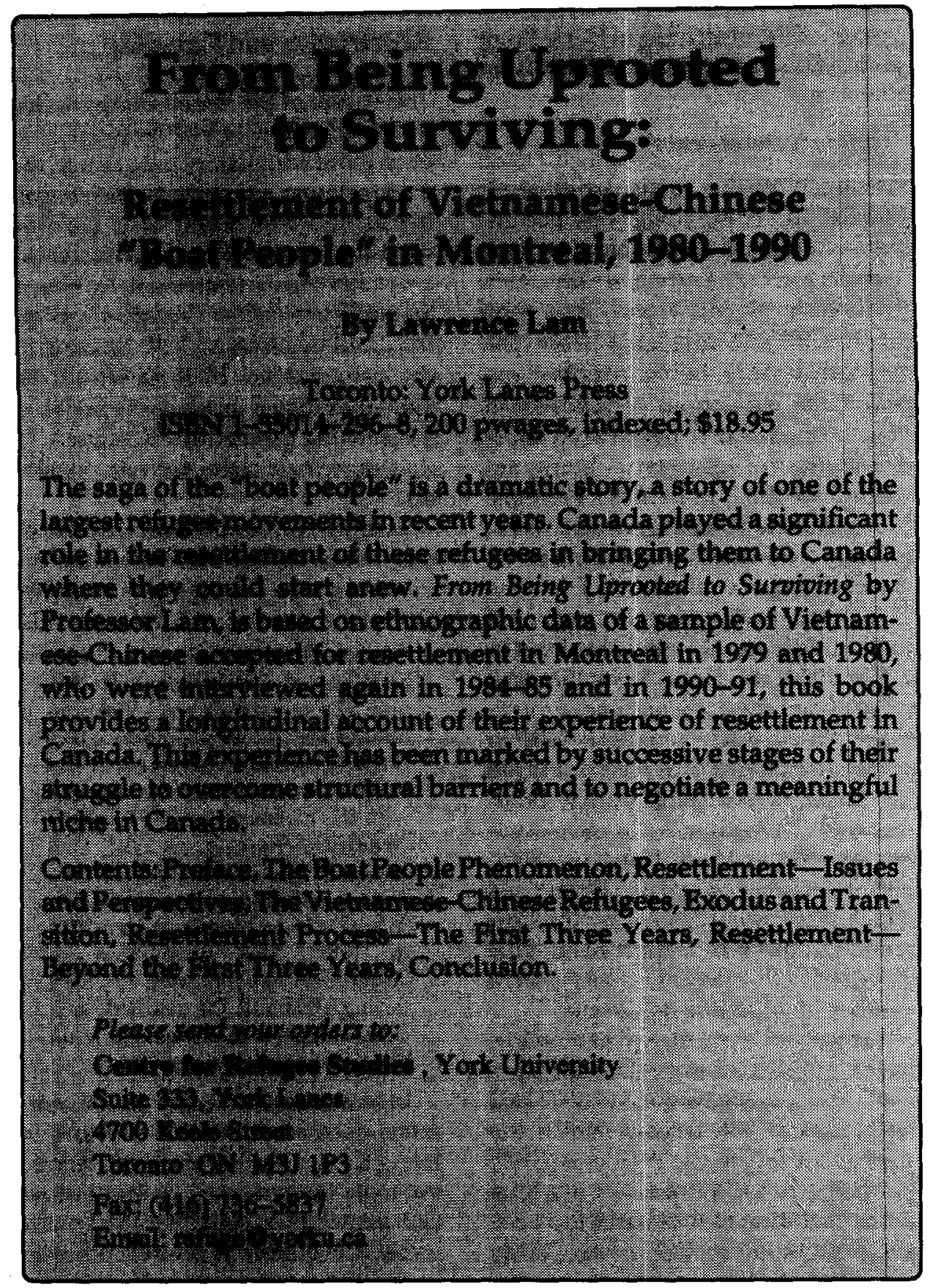

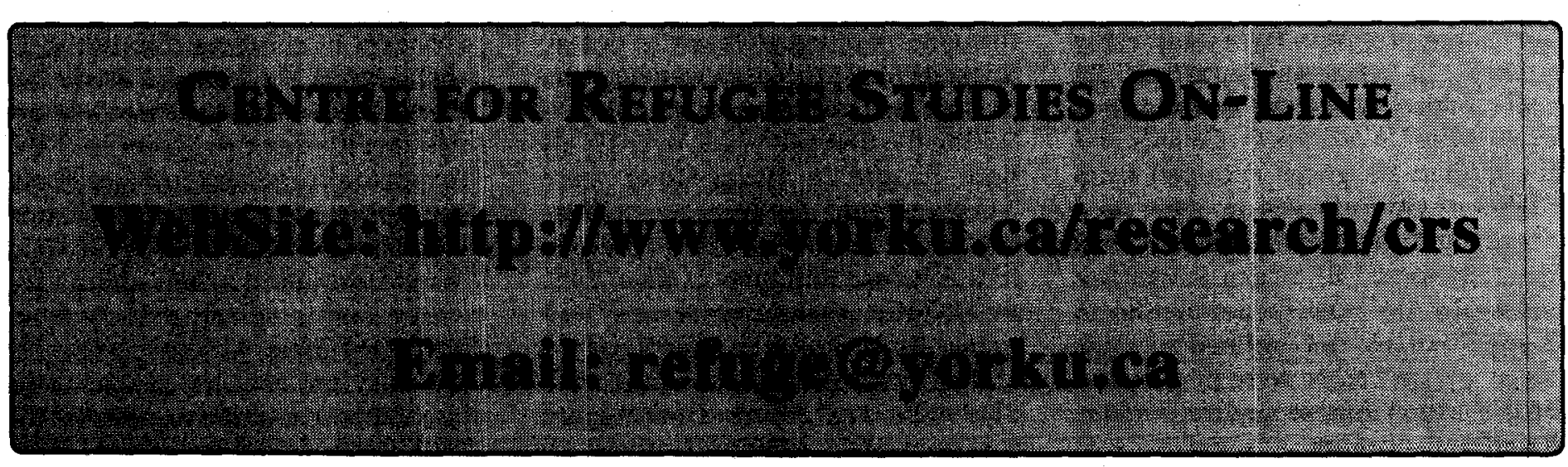

(C) Alex Cunliffe, 1997. This open-access work is licensed under a Creative Commons Attribution-NonCommercial 4.0 International License, which permits use, reproduction and distribution in any medium for non-commercial purposes, provided the original author(s) are credited and the original publication in Refuge: Canada's Journal on Refugees is cited. 